\title{
A tér a marketingben
}

\section{Space in marketing}

\section{KOVÁCS ANDRÁS}

KOVÁcS András: főiskolai docens, Budapesti Gazdasági Egyetem, Kereskedelmi, Vendéglátóipari és Idegenforgalmi Kar, 1054 Budapest, Alkotmány u. 9-11. Kovacs.Andras@uni-bge.hu

KULCSSZAVAK: tér; marketing; geomarketing; regionális tudomány

ABSZTRAKT: A tér és térbeliség napjainkban sem játszik fontos szerepet a különféle szervezetek marketingtevékenységében. Tanulmányunkban - a térbeliség és a marketing alapfogalmainak áttekintését követően - bemutatjuk, hogy az üzleti gondolkodásban, a piacokról folyó diskurzusban, illetve ezen belül különösen a stratégiai marketingben mely területeken azonosíthatók térbeli problémák.

A marketing térvonatkozásainak elméleti megalapozásához röviden ismertetjük a társadalmi térfogalom különféle megközelítéseit a társadalomtudományokban (regionális tudomány, társadalomföldrajz, közgazdaságtan, szociológia). A tér elméleti és alkalmazott közgazdaságtani értelmezését követően foglalkozunk a marketingre vonatkozó elképzelésekkel.

Röviden bemutatjuk a marketing hazai és nemzetközi fogalmi megközelítéseit, és a marketing kotleri értelemben vett (tágan értelmezett) modelljét felhasználva emeljük ki annak explicit és implicit térvonatkozásait, rámutatunk a termék, az ár, az értékesítés és a kommunikációs stratégia térbeli sajátosságaira, a kapcsolati marketing, a társadalmilag felelős marketing és belső marketing területi aspektusaira. Számos példával illusztráljuk, hogy a marketing erőteljesen térbe ágyazott, így amellett érvelünk, hogy a hatékonyabb marketinggondolkodásban figyelembe kell venni a térbeli kapcsolódásokat, területi meghatározottságokat.

A geomarketing-gondolkodásmódban, melynek szükségességére hívjuk fel a figyelmet, a térbeliség nem szükül le a telephelyválasztásra és az értékesítéstervezésre, hanem áthatja a marketing egészét.

András KOVÁCS: associate lecturer, Budapest Business School, Faculty of Commerce, Catering and Tourism, H-1054 Budapest, Alkotmány street 9-11. Kovacs.Andras@uni-bge.hu

\section{KEYWORDS: space; marketing; geomarketing; regional science}

ABSTRACT: Space and spatiality still do not play a significant role in organizations' marketing activities. The study - after a brief revision of the basic concepts of spatiality and marketing - introduces those areas in business approach, market discourse and especially in strategic marketing where space-related problems prevail.

In order to give a detailed explanation on spatial problems in marketing, the paper first introduces space theories and social scientific approaches to space (regional science, economics, sociology, and human geography). After that, it will discuss theoretical and applied economic considerations with a special focus on spatiality in marketing.

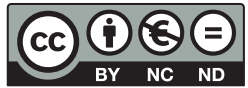


It will also introduce a number of international and Hungarian definitions - searching for spatiality in marketing - and, finally, it will analyze different explicit and implicit marketing relations of space on the basis of Kotler's holistic marketing approach. In this main part, we will point out how and which way space and different space-interpretations (e.g. physical space, relational spaces and subjective spaces) affect (or should affect) marketing in theory and practice.

Based upon Kotler's holistic marketing concept, we will point out spatial features in product, price, place and promotion strategies, as well as the spatial aspects of relationship marketing, CSR marketing and internal marketing. Supported by several examples, we evince that marketing is rather "embedded in space", so, as the argument goes, spatial connections and spatial features should be considered seriously in an effective marketing approach and even in everyday work.

We also highlight that in a "geomarketing" approach spatiality does not simply refer to site selection and sales planning, but it also applies to the entire marketing process: Market analysis has a spatial character, because markets have spatial extent both in geographic and cyber spaces. Companies' market position are influenced by competitors, suppliers and customers, among others, with their own geographical location and, therefore, they should consider the utilization of it for location-based advantages. Marketing part-strategies (e.g. product, price, communication) also have spatial dimensions if we accept that markets have a spatial character and they differ (also) in spatial terms from one another. And finally, customers, employees, stakeholders and other members of the society have different spatial perceptions, which companies have to consider when elaborating and carrying out their marketing activities.

\section{Bevezetés}

Tanulmányunk a Tér és Társadalom hasábjain az elmúlt években kialakult térelméleti és értelmezési diskurzushoz kíván kapcsolódni. Azonban nem a „térvita" elméleti vonatkozásait kívánjuk újabb adalékokkal gazdagítani, hanem a tér és térbeliség eddigi üzlettudományi, azon belül kifejezetten a marketingre vonatkozó értelmezésével foglalkozunk. A térfogalom elméleti közgazdaságtudományi (economics) valamint üzlettudományi (business science), ezen belül marketingszempontú értelmezése és alkalmazása egyaránt leszűkíto", ezért tanulmányunkban azt a célt tüztük ki, hogy bemutassuk a térforgalmak és térinterpretációk üzlettudományi alkalmazhatóságának lehetőségeit és relevanciáját. Arra törekszünk rávilágítani, hogy hogyan és milyen mértékben járulhatnak hozzá a térbeli szemléletmód és térbeli (piac)elemzési módszerek és technikák a vállalati marketing munkahatékonyságának növeléséhez, ezáltal a vállalati profitmaximalizálási cél eléréséhez. Célunk, hogy a marketinggondolkodás, stratégiaalkotás és megvalósítás egészére kiterjesszük a regionális (területi) tudományra jellemző összetett térszemléletet.

Tanulmányban felvázoljuk a tér fogalmát és értelmezési lehetőségeit, majd meghatározzuk a marketing fogalmát és feladatait. Ezt követően foglalkozunk a marketing (ezen belül a stratégiai marketing) térvonatkozásaival, vagyis azzal, hogy a marketingen belül „hol” milyen fontossággal azonosítható a „térbeli dimenzió”. 


\section{Regionális tudomány és marketing}

Természetesen nem kívánunk vitát indítani arról, hogy akár a marketing, akár a regionális tudomány önálló társadalomtudománynak tekinthető-e, illetve ha nem, akkor ennek milyen következménye van (nincs) az e témákban folyó különféle kutatásokra. Az önállóságtól függetlenül bizonyosan állithatjuk viszont, hogy mind a regionális tudomány, mind pedig a marketing fontos társadalmi és gazdasági kérdéseket tárgyal a maga területén. Megítélésünk szerint akár mindkét „tudományra” illeszkedik Enyedi György találó, máig aktuális megállapítása, miszerint a regionális tudomány transzdiszciplináris tudáskészlet (Enyedi 2002, 63.).

Napjainkig - különösen a hazai szakirodalomban - viszonylag ritka a térbeliség és az üzlettudományok valamely aspektusa (így a marketing) összekapcsolására tett kísérlet, a mainstream kutatások egyik szakterületen sem ebbe az irányba haladnak. Rechnitzer János a hazai regionális tudomány fö kutatási területei között nem említi (Rechnitzer 2005), viszont Lengyel Imre kívánatos célként fogalmazza meg az ilyen témában történő oktatás és kutatás hazai fejlesztését (Lengyel 2010). Ennek ellenére a hazai felsőoktatási tantárgyak között - sem a gazdaságtudományokban, sem a geográfus felsőoktatásban - nem (vagy alig) jelenik meg a térbeliség üzleti problémáinak oktatása.

Természetesen ez nem azt jelenti, hogy a hazai regionális vagy éppen az üzleti kutatás egyáltalán ne foglalkozna üzleti jellegü térbeli problémákkal. Egy-egy specifikus területen, mint a fogyasztói magatartás (Kozák 2010), a kiskereskedelem (Kovács 2013; Sikos T. 2012), vagy éppen a városmarketing (Kozma 1995; Piskóti 2012) és a regionális versenyképesség (Rechnitzer 2016) területén születtek tanulmányok, azonban ezek közös jellemzője, hogy egy-egy ágazat, üzleti probléma, vagy éppen a térség marketingszempontú elemzésével foglalkoznak, nem céljuk a térprobléma üzleti vonatkozásainak általános vizsgálata.

Tanulmányunkban különösen a marketing és a térbeliség komplex elemzésére koncentrálunk - mikroökonómiai szempontból, vagyis a vállalatok nézőpontjából. (A régió és a település marketingjellegü térértelmezésével nem foglalkozunk a továbbiakban.) Ehhez szükségesnek tartjuk a térértelmezés, a térbeliség és a piaci folyamatok kapcsolódásának, valamint a marketing fogalmi kereteinek tisztázását.

\section{Térértelmezések}

A tér definíciójának, fogalmi fejlődésének, értelmezési lehetőségeinek rövid bemutatása is messze meghaladná e tanulmány terjedelmét, a továbbiakban azokat a térfogalmakat és térrel kapcsolatos elméleti megközelítéseket kívánjuk felsorolni, melyek tanulmányunk szempontjából fontosak. A vállalatok marke- 
tingjének térbeli aspektusaival kapcsolatban áttekintjük azokat a térinterpretációkat, melyek közelebb vihetnek a térbe integrált marketing megértéséhez. A vállalatok üzleti és marketingtevékenységeit elemezve a fö kérdés az, hogy az üzleti, vállalati folyamatok rendelkeznek-e, és ha igen, milyen jellegü térbeli sajátosságokkal, valamint hogy a térbeliség mennyire meghatározó a vállalatok üzleti stratégiájának megvalósításában.

A tér fogalmának és lehetséges interpretációinak fejlődése nagy utat járt be. Benedek József mutat rá nagy ívü összegző esszéjében, hogy az abszolutista („tartályszerü”) térkoncepció, valamint a relacionális, vagyis egymás mellett létező dolgok viszonyrendszeréből felépülő tér koncepciója már a 16. században megjelent és napjainkig "használatban” maradt (Benedek 2002). A vállalatok marketingstratégiája szempontjából mindkét térkoncepció nagy jelentőségű. Egyetértünk Erdősi Ferenccel, aki a relacionális térviszonyok mellett kiemeli a földrajzi (háromdimenziós) tér felértékelődését az utóbbi évtizedekben (távérzékelés, helymeghatározás stb.) (Erdősi 2014). A vállalati marketinginformációs rendszer számára a vállalat Facebook-oldalát követők kapcsolati hálója (mint relacionális térstruktúra) ugyanolyan fontos lehet, mint a vállalat üzletének közelében tartózkodó vásárlók (a földrajzi térben való) jelenléte (akik számára azonnali e-mailes reklámüzenet küldhető a vásárlási szándékukat ösztönzendő). A posztmodern földrajzban fontos megemlíteni az elsősorban Henri Lefebvre és Edward Soja nevéhez kötődő térfelfogást, mely a terek szubjektív percepcióját emeli ki: az érzékelt első tér és az elgondolt második tér mellett megjelenik a megélt harmadik tér is (Berki 2015; Soja 1989).

E térértelmezések a vállalatokkal és a marketinggel kapcsolatos fontos problémákra irányítják a figyelmet, egyrészt a „külső” és „belső” terek sajátosságaira, másrészt a kibertér és a földrajzi tér sajátosságaira és kapcsolódási pontjaira, harmadrészt a térérzékelés szubjektivitására.

Nemes Nagy József tértipológiájában elkülöníti az ún. „külső” és „belső” tereket (Nemes Nagy 2009). A külső (földrajzi) terek a vállalati marketingstratégia szempontjából úgy artikulálódhatnak, mint üzleti telephelyek vagy vonzáskörzetek, a belső terek pedig a vállalati telephelyhálózatok vagy az üzleti vonzáskörzetben élők kapcsolati hálóinak leképeződései lehetnek. A példánkban tárgyalt térelemek és azok kapcsolódásai egyaránt értelmezhetőek és elhelyezhetőek egy (vagy több) külső és belső térben is. Egyetértek Faragó László állításával, miszerint egy bevásárlóközpont eladási lehetőségeinek elméleti vizsgálatánál kiemelendők a relacionális terek, azonban vitatom azt a megállapítását, hogy az abszolút tér és távolság ne lenne meghatározó (pl. utazási idő és költség vonatkozásában) (Faragó 2012).

A külső-belső térinterpretációk mellett fontos kérdéskör a kibertér (az internet tere) és annak földrajzi térbeli kapcsolódási pontjainak vizsgálata. Mészáros Rezső és Jakobi Ákos rámutatnak e két tér sajátosságaira, és a köztük lévő kapcsolódásokra (Jakobi 2007; Mészáros 2001). Az üzleti sikerességre tö- 
rekvő vállalatok számára egyértelmű és meghatározó fontosságú, hogy milyen módon és mértékben képesek definiálni magukat a földrajzi (fizikai) térben és a kibertérben, illetve mennyire képesek azonosítani azokat a marketingfeladatokat, melyek versenyelőnyt biztosítanak számukra a konkurens vállalatokkal szemben. Ahhoz, hogy erre képesek legyenek, egyaránt el kell igazodniuk a földrajzi és a kibertérben is.

Henri Lefebvre és Edward Soja nyomán Berki Márton (2015) értelmezi az ún. harmadik tér (megélt tér) fogalmát, mely egyre fontosabb, nemcsak földrajzi vagy társadalomtudományi, de üzleti és marketingszempontból is. Ebben az esetben nem az objektív háromdimenziós térről, vagy az abból leképezett konstrukciókról (térképek, tervrajzok) beszélünk, hanem azokról az egyéni élményekről, tapasztalatokról, amelyeket a megfigyelő az adott térben szerez. Ezek lehetnek egyéni élmények és benyomások egy városközpontban történő vásárlás, vagy egy bevásárlóközpontban a kávézás során, vagy éppen egy bolyongás alkalmával egy hipermarketben. A térnek e szubjektív percepciója számos üzleti területen fontos lehet, például bevásárlóközpontok belső morfológiájának kialakításában, városmag-rehabilitációs projektekben a tér funkcionális tervezésében, hipermarketekben a vevőáramlás optimalizálásában. Vagyis az általános térfogalomnak és térérzékelésnek kiemelten fontos a társadalomtudományi (szociológiai) interpretációja és magyarázata. A tér ugyanis nemcsak külső objektív létező, hanem a társadalom és annak tagjai által „teremtett" tér is, ahogy erre Giddens rámutat strukturációs elméletében (Berger 2013). Nemcsak mozgunk a külső térben és időben, hanem magunk is aktívan hozzájárulunk a terek létrehozásához, fennmaradásához, megszűnéséhez: a tér hat ránk és mi is hatunk a térre. A találkozási csomópontok, naponta ismétlődő (közlekedési) rutinok, cselekvések a térben és az időben való tagolódása, a különféle társadalmi csoportok jelenléti elérhetősége nemcsak a szociológia, hanem az üzleti tudományok (marketing) számára is fontos kiindulópont.

\section{Tér és piac - piactér?}

A piac fogalmát a közgazdaságtan legáltalánosabban úgy határozza meg, hogy a „kereslet és kínálat találkozásának helye”, mely azonban nem (feltétlenül) egy adott földrajzi ponthoz, térséghez kötődik, hanem egy képletes térbeli pont vagy éppen térnélküli entitás. Az elméleti közgazdaságtanban a legutóbbi időkig ez a térnélküli szemlélet egyeduralkodó volt, Krugman munkásságához köthető a „new economic geography” (új gazdaságföldrajz), a térbeliség beépítése a közgazdasági modellekbe (Krugman 1999), azonban a Krugman-féle „költségtávolság”-szemlélet leszűkíto (Gál 2012). A „térnélküli közgazdaságtan” máig szinte egyeduralkodó a közgazdaságtudományi felsőoktatásban, aminek oka 
egészen Marshallig vezethető vissza. A sokat idézett mondata: „A piacok különbözőek abból a szempontból, hogy a kereslet és kínálat mennyi idő alatt tudja kiegyenlíteni egymást, valamint hogy mekkora területre terjednek ki. Az időtényező most több figyelmet igényel, mint a tér." (Marshall 1920, 192.) Az idézet utolsó mondata érzékelteti, hogyan viszonyulnak a közgazdászok a térbeli problémákhoz, legtöbbször nem is azonosítják a probléma térbeli karakterét. Ez egyaránt probléma az elméleti, illetve az alkalmazott közgazdaságtanban, azonban utóbbiban még szembetűnőbb, hiszen nyilvánvaló, hogy a gazdasági és társadalmi folyamatoknak meghatározó térbelisége van, mely számos területen befolyásolja a vállalatok müködését (így a marketingben is). Amíg azonban a térbeli-gazdasági problémák elméleti vonatkozásainak széles körü szakirodalmi forrásai állnak rendelkezésre (Dusek 2013; Lengyel, Rechnitzer 2004), addig az üzleti, marketingproblémák holisztikus térrelációinak tárgyalása - különösen a hazai irodalomban - igen korlátozott.

A piac térbeli kiterjedésének problémájára a kibertér és a földrajzi tér értelmezéseinek során térünk ki. A piac térbeli, többféle közelítésben:

- a piac, ahol a tranzakció létrejön, kialakul, megvalósul (fizikai hely, digitális piactér vagy a kettő kombinációja: a „marketplace” és a „marketspace" fogalmak különböznek);

- a piac, amely területen, területeken (egy vállalat) termékeket ad el (globális, országos, regionális, lokális szinten);

- a piac, ahol a vásárlók találhatók, elérhetők (a földrajzi térben, a kibertérben).

Ebből következik, hogy a piac térbeli jellege a marketingfilozófiában és a marketingmunkában egyaránt meg kell, hogy jelenjen - a makrokörnyezet elemzésétől a piacok felderítésétől és lehatárolásától (piackutatás) a piacszegmentáción át egészen a marketingstratégia kidolgozásáig és megvalósításáig.

A vállalat irányítóinak fontos tudnia, hogy piacai „hol terülnek el” a földrajzi térben és a kibertérben; az egyes piacokon mekkora a potenciális vásárlók száma (piacpotenciál), ezek milyen hatékony (térben is értelmezett) marketingeszközökkel érhetők el; valamint mindezt milyen (térbeli adottságokkal is rendelkező) makrokörnyezeti meghatározottságok és versenykörnyezeti sajátosságok befolyásolják. A piacok térszerkezetének és területi folyamatainak kutatása - elsősorban földrajzi, térinformatikai megközelítésben - megtalálható a nemzetközi szakirodalomban, a tudományos világban és az üzleti alkalmazásban. Példák ezekre a térinformatikai felfogású GIS for business and service planning c. kötet (Longley, Clarke 1996), a GfK piackutató szintén térinformatikai alapú geomarketingszoftverje (RegioGraph) és honlapja (www.gfk-geomarketing.com) és rendszeresen megjelenő magazinja (Geomarketing), valamint Youtube- és Twittercsatornája. Napjainkra a geomarketing - különféle tértudományi megközelítésben jelentős nemzetközi szakirodalommal rendelkezik (Douglas 2008; Grimshaw 2000; Pick 2004), azonban a szerzők ritkán foglalkoznak marketingszempontból a térproblémával (Cliquet 2006). 


\section{Marketingfogalmak és -értelmezések}

Ahhoz, hogy tisztázni tudjuk a tér szerepét a marketingben, fontos a marketing fogalmának pontos definiálása. Bauer András és Berács József a marketinget három szinten értelmezi (Bauer, Berács 2006, 12.):

- Szűken értelmezve: „olyan vállalati tevékenység, amely a vevők/felhasználók igényeinek kielégítése érdekében elemzi a piacot, meghatározza az eladni kívánt termékeket és szolgáltatásokat, megismerteti azokat a fogyasztókkal, kialakítja az árakat, megszervezi az értékesítést és befolyásolja a vásárlókat."

- Tágabban értelmezve: „a vállalat egészére kiterjedő - a vevőkkel való azonosulást hangsúlyozó - filozófia, szemléletmód, amelynek megvalósítása a vállalati felső vezetés feladata, oly módon, hogy a vállalati résztevékenységek integrációjában a marketingszempontok domináljanak."

- Kiterjesztett értelemben: „minden értékkel rendelkezo jószág (termék, szolgáltatás, eszme, ötlet, érzés stb.) cseréje. Az üzleti vállalati szférán túl kiterjed az olyan, nem nyereségorientált területekre is, mint pl. oktatás, kultúra, vallás, politika stb."

Rekettye Gábor és szerzőtársai szerint a marketing „szemléletmód és eszközrendszer. A marketing-szemléletmód nem más, mint a képesség, amely a figyelem középpontjába a fogyasztót, a felhasználót - összefoglaló néven a vevőt - állítja. Az ilyen szemléletmód alapján dolgozó vállalat arra törekszik, hogy kínálata minél jobban megfeleljen a vevők igényeinek, a termékei, szolgáltatásai minél nagyobb értéket jelentsenek számukra. A vevő számára történő értékesítés megfelelő eszközrendszert igényel. Ez a marketing alkalmazásának másik fontos aspektusa" (Rekettye, Törőcsik, Hetesi 2015, 25.).

A Bauer és Berács szerzőpáros, illetve Rekettye és szerzőtársai marketingdefinícióiban a marketing egyrészt tevékenység, másrészt szemléletmód, amely kiterjed a vállalat egészére, és melynek célja különféle értékekkel bíró dolog értékesítésének támogatása adott piacon. A piac meghatározására és lehatárolására azonban nem tesznek utalást, így nem határoznak meg piacokat, piactípusokat (sem földrajzi, sem más szempontok szerint), meghatározásukban a közgazdaságtanban jól ismert „térnélküli” piacfogalom tükröződik.

Sikos T. Tamás Marketingföldrajz címü összegző művében rávilágít a marketing- és térbeli szempontokat (is) figyelembe vevő térorientált marketing fontosságára, amikor így fogalmaz: „A marketingföldrajz célja tehát különböző országok marketingrendszereiben fellelhető hasonlatosságok és különbségek elemzése, rendszerek fejlődésének előrejelzése" (Sikos T. 2000, 29.). Sikos T. kiemeli a marketing térbeli értelmezésének és gyakorlásának fontosságát, azonban nem általában értelmezi a teret, hanem országos szintű összevetésről ír fogalommeghatározásában. Sikos T. fogalmi meghatározásának térbeli közelítését általánosítva juthatunk el a térmarketing általános leírásához. 
Ezek szerint a marketing egy-egy specifikus külső és/vagy belső térben meghatározott piacon található vásárlók szükségleteinek kielégítése érdekében valósul meg. A marketing komplex szemléletmód, eszközrendszer és gyakorlat.

Ez az értelmezés felhívja a figyelmet a piacok térbeli meghatározottságára, kiterjedésére, valamint a marketing piacfüggőségére, vagyis arra, hogy a marketingszemlélet és -gyakorlat megvalósítása mindig az adott piac viszonyainak függvénye. Rávilágít arra is, hogy a piac mint térbeli entitás és az adott piacon megvalósítandó marketing között kapcsolat van. Rövid távon a piaci viszonyok határozzák meg a marketinget, hosszabb távon azonban az eredményes marketing képes megváltoztatni a piaci viszonyokat, a piac sajátosságait, akár szerkezetét is, így a kapcsolat kölcsönös.

Fontos kiemelni, hogy a piacok térbeli értelmezésekor a tér fogalmát a Nemes Nagy-i értelemben használjuk, vagyis a piac mint térbeli entitás egyaránt viselhet a külső térre, illetve a belső térre jellemző elemeket: piac lehet egy bevásárlóközpont földrajzi térre értelmezett vonzáskörzete (pl. a tatabányai Vértes Center vonzáskörzete), de piac lehet a World of Tanks nevű online internetes játék játékosainak kapcsolati tere is. A fenti két példában közös, hogy mindkettő értelmezhető piaci térként és térbeli piacként, mert mindkettőnek megvan a maga topológiája, mindkét térben elhelyezhetők és jellemezhetők a fogyasztók, mindkét térben értelmezhető az egyes fogyasztó helye és helyzete, így mindkét piacon értelmezhető és megvalósítható a komplex marketingmunka.

Annak tisztázása érdekében, hogy mennyire fontos és releváns a térbeliség a marketingben, vagyis hogy „érdemes-e” a piac és marketing általános térbeli értelmezésével foglalkozni, Kotler holisztikus marketingmodelljét hívjuk segítségül. Kotler holisztikus marketingmodellje olyan törekvés, melyben a marketing értelmezési tartománya kiterjed a vállalatra és teljes piaci kapcsolatrendszerére (az összes stakeholderre) (Kotler, Keller 2012). A holisztikus marketingmodellnek négy fö területe van, melyek további részterületekre bomlanak:

- Integrált marketing (termékek és szolgáltatások, kommunikáció, árak, értékesítési csatornák);

- Társadalmi felelősségre épülő marketing (etika, környezet, közösség, törvényesség);

- Kapcsolati marketing (vevők, csatorna, partnerek);

- Belső marketing (marketingosztály, felsővezetők, egyéb osztályok).

A modell már nemcsak a szűken vett termékmarketingre koncentrál (termékfejlesztés, árazási kérdések, értékesítés), hanem olyan, a vállalati sikerességet hosszú távon befolyásoló tényezőkre is, mint a társadalmi felelősségvállalás (környezetvédelem, szociális érzékenység), kapcsolati marketing és belső marketing (folyamatos kapcsolattartás a vállalat vevőivel, beszállítóival, partnereivel, valamint a belső munkatársakkal, a vállalat más részlegeivel). A holisztikus marketingmodellben jól érzékelhető, hogy a hagyományos értékesítés-központú, mennyiségorientált marketing mellett megjelennek új elemek, melyek a 
marketing fontosságát nemcsak a vállalat-vevő kapcsolatban értelmezik, hanem vállalat-környezet, vállalat-munkavállalók stb. relációkban is.

\section{Térbeliség a marketingben}

A marketing egyes területeinek térbeli jellege már hosszú ideje ismert, a geomarketing pontosan azokkal a területekkel foglalkozik, melyekben eddig is nyilvánvaló volt a térbeli relevancia. Cliquet Geomarketing című összefoglaló műve három fontos területre összpontosít (Cliquet 2006):

- fogyasztói magatartás és földrajzi információk,

- kereskedelmi telephelyválasztás és földrajzi információk,

- marketingmenedzsment és földrajzi információk.

A Cliquet müvében megjelölt három fontos, térvonatkozású téma közül az első kettő a hazai szerzők körében is jól ismert, Sikos T. Tamás, Kozák Ákos, Kovács András és mások müveiből. Cliquet értelmezésében a harmadik pontban szereplő marketingmenedzsment térbeli vonatkozásai a McCarthy-féle 4P-modell logikáját követik, vagyis rávilágítanak a termékstratégia, az árstratégia, az értékesítési, disztribúciós stratégia és a kommunikáció térbeli sajátosságaira. A stratégiai szempontú piacelemzés és marketingtervezés területén azonban nemcsak a nemzetközi, hanem a hazai szakirodalomban is található utalás és példa a térbeliség, a térbeli adatok elemzésének fontosságára, különösen a makroelemzés és a disztribúciós stratégia kialakítása területén (Józsa 2014).

Azonban Cliquet geomarketing-értelmezése, valamint a fent említett hazai szerzők térközelítése is csak részleges. E tanulmány célja az, hogy a lehető legtágabban értelmezve mutassa be a tér jelentőségét a marketingben, felhasználva ehhez Kotler holisztikus marketingmodelljét. Erre a modellre építve mutatjuk be a marketing térdimenzióit, mindazokat a térértelmezéseket, melyek a holisztikus marketingmodellben explicite vagy implicite megtalálhatóak.

\section{Tér az integrált marketingben}

Az integrált marketing sommásan a 4P (product, price, place, promotion), 4C (customer value, cost, convenience, communication) vagy éppen (a szolgáltatások esetében) a 7P (product, price, place, promotion, people, process, physical evidences) modell gyakorlati megvalósítását jelenti, vagyis a termék, ár, értékesítési és promóciós, kommunikációs stratégia megtervezését és gyakorlatba ültetését (szolgáltatások esetében kiegészítve a szolgáltatást nyújtó személyek, folyamatok és fizikai körülmények kialakításának feladataival). A marketingen belül a nemzetközi marketing foglalkozik általában a különböző piacokat (jelen 
esetben a piacok többé-kevésbé országok szinonimáinak tekinthetők) érintő marketingfeladatokkal (Rekettye, Tóth, Malota 2015), azonban ennél általánosabb térvonatkozású értelmezéseket csak a marketingstratégia specifikus P-jénél, a disztribúciós és értékesítési csatorna politikáinál találhatunk. A továbbiakban számba vesszük az integrált marketing P-jeit, és rávilágítunk azok térbeli jellegére, térkapcsolataira.

Rendhagyó módon nem a termékstratégia (product) kifejtésével kezdjük, hanem a hely és az értékesítési csatorna stratégiájának (place) áttekintésével, hiszen itt a leginkább egyértelmű a földrajzi kötődés, a térbeliség jelenléte. Az értékesítési csatorna és az értékesítés helyének meghatározása az elmúlt években új megvilágításba került az online értékesítési csatorna megjelenésével. A földrajzi tér mellett/helyett megjelent a kibertér mint értékesítési „hely”, ami új kihívást jelent a vállalatok számára. A vállalat értékesítési rendszerét fejleszteni kellett, figyelembe véve a vállalat profilját, stratégiai céljait, a versenytársak értékesítési stratégiáját stb. Napjainkra a sikeres vállalatok hagyományos és online értékesítési csatornával egyaránt rendelkeznek (az online kereskedők offline csatornát nyitnak - pl. Extreme Digital, az offline értékesítők pedig megjelennek az online piacokon - pl. Tesco, Rossmann), illetve profiljukhoz illesztve, a vállalati szinergiákat kihasználva ötvözik a két csatorna előnyeit (pl. Libri - könyvátvétel a könyváruházakban).

Az értékesítés helye fontos más szempontból is, ahogy erre a szubjektív térpercepciók tárgyalása során már utaltunk. Az eladás helye (tere) nemcsak mint fizikai tér értelmezheto”, hanem önmagában „élmény”, akár pozitív, akár negatív értelemben. Az eladás helyét (legyen ez egy bevásárlóközpont, egy belvárosi piac, egy hipermarket, egy bemutatóterem vagy akár kisbolt) mint szubjektív térpercepciót is meg kell határozniuk a vállalatoknak. Az eladótérnek, illetve a szolgáltatásnyújtás terének kialakítása és müködtetése során azok térélmény jellegét is tudatosan formálni kell, figyelembe véve a célcsoport(ok) térhasználati preferenciáit.

Az értékesítési stratégia könnyen értelmezhető térbeli karaktere mellett fontos hangsúlyozni, hogy az általunk tárgyalt térbeliség messze nem korlátozódik a marketingstratégia e szegmensére, hanem általánosan, az egész marketinggondolkodást (mint filozófiát) és -tevékenységet át kell hatnia.

A termékstratégia (product) térbeli vonatkozásainak értelmezése már nem ennyire közvetlen. Azonban ebben az esetben is fontos látni - mivel a gazdaság és a társadalom térben szerveződik -, egy sikeres termékstratégia nem nélkülözheti a térbeli dimenziót. Ahhoz, hogy megértsük a termékstratégia tervezésének térbeli vonatkozásait, tudnunk kell, hogy a fogyasztói preferenciák nem homogének, így a sikeres termékstratégia térben (is) differenciált és igazodik a vásárlói/fogyasztói igényekhez. Például egy csokoládé- és üdítőautomatában kínált optimális termékportfóliót a lokális piaci igényekhez (térbeli sajátosság) kell igazítani; egy franchise rendszerben működő gyógyszertárhálózat egységeinek kínálata is a lokális igényekhez kell, hogy igazodjon; egy mezőgazdasági és 
kertészeti gépeket gyártó vállalkozás is a földrajzi adottságokhoz igazodó kínálattal kell, hogy a piacra lépjen. Összességében tehát a termékstratégia kialakítása és megvalósítása során a térbeli sajátosságokra is összpontosítani kell, akkor is, ha a termék dematerializált (nem jelenik meg anyagi formában), vagy szolgáltatás(jellegü). Erre példa, hogy egy SaaS-filozófiában (software as a service) müködő online üzleti alkalmazást (pl. vállalatirányítási rendszer) „lokalizálni” kell az adott piaci körülményekhez: nyelvi, adózási, ügyfélszolgálati beállítások stb.

Az árstratégia (price) megvalósítása során felmerül bizonyos szempontok szerinti árdiszkrimináció alkalmazásának lehetősége. Az ún. harmadfokú árdiszkrimináció csoportjába tartozik, ha az adott vállalat egyes részpiacokon eltérő áron értékesíti termékét, szolgáltatását. Esetünkben, amennyiben a részpiacok területi jellegzetességgel rendelkeznek, a harmadfokú árdiszkriminációnak térbeli jellege van. A gyakorlatban számos esetben találunk példát olyan kereskedelmi vállalkozásokra, melyek üzlethálózatukat különböző kategóriába sorolják a helyi piaci kereslet-kínálati viszonyok alapján, és árszínvonalukat ehhez igazítják. A különböző kategóriába sorolt üzletek átlagos árszintje jelentősen eltérhet egymástól. Az ilyen módon differenciált árstratégia sokkal jobban igazodik a lokális piaci kereslethez, azonban alkalmazásához elengedhetetlen a menedzsment térbeli szemlélete, valamint olyan marketinginformációs és döntéstámogató rendszerek alkalmazása, melyek az üzlethálózat egységeit képesek elkülönülten kezelni, mindegyik csoport számára adekvát marketingkommunikációt kidolgozni és megvalósítani (példaként lehet említeni az üzemek területén működő boltok alacsonyabb vagy az autópályák mellett üzemelő benzinkutak magasabb árait). Ezzel szemben a nem differenciált árazás előnye, hogy alkalmazása egyszerü, azonban ez azt a redukcionista szemléletet tükrözi, hogy a piaci keresleti-kínálati viszonyok homogének, ami általában távol áll a valós helyzettől.

A térben differenciált árstratégia fontos kérdéseket vet fel a különböző értékesítési csatornákon történő eladások kapcsán is. Napjainkban, amikor a hazai kiskereskedelmi forgalom több mint $4 \%$-át teszi ki az online értékesítés, valamint további komoly fejlesztések várhatóak - ugyanis jelentős kiskereskedelmi vállalatok lépnek az online piacra 2016-ban és 2017-ben (pl. Auchan, Interspar) (www.hvg.hu) -, akkor fontos térvonatkozású kérdés, hogy az egyes értékesítési csatornákon milyen árazást alkalmaz a vállalkozás. A hagyományos értékesítés, a házhozszállítás, a postapontok, trezorok, bolti átvétel stb. eltérő költségei fontos árképző tényezőnek számítanak. A vállalatoknak nemcsak azt kell mérlegelni, hogy milyen értékesítési csatornákon keresztül juttassák el termékeiket a vásárlóknak, hanem azt is, hogy az egyes értékesítési csatornák számára milyen árképzést alakítsanak ki, hogyan építsék be a „csatorna árát” a termék árába. Különösen nagy kihívást jelent ez a relatíve alacsony árú termékek esetében (pl. használt tömegcikkek, kis értékủ ajándékok stb.), ahol a szállítási költség akár meg is duplázhatja egy-egy termék árát.

A promóciós, kommunikációs stratégia (promotion), legyen ez akár online, akár offline, illetve a kettő kombinációja, számos területen térbeli jellegzetes- 
séggel rendelkezik. Szűkebben értelmezve egyes reklámhordozók földrajzi elhelyezkedése miatt fontos annak meghatározása, hogy az üzenet a földrajzi térben hol jelenjen meg úgy, hogy a célcsoport nagyobb részét a leghatékonyabban elérje (pl. óriásplakátok, citylightok esetében). Egy-egy célcsoport lakhelye, illetve napi, heti ingázási sajátosságai kijelölhetik a földrajzi térben azokat az optimális helyeket, ahol a legnagyobb elérés biztosítható a reklámüzenet küldője számára. Hasonlóan fontos információ lehet egy üzlet földrajzi vonzáskörzete, amely magától értetődően határozza meg a szórólapos vagy egyéb kommunikáció térbeli határait, ezzel jelentős költséghatékonyság-növekedést biztosítva a marketingkommunikációban. Olyan mikroterekben - mint egy bevásárlóközpont vagy hipermarket belső tere (pl. plázamédia, belső eladási, helyi, ún. PoS-eszközök) - is fontos a kommunikációs üzenetek optimális térbeli elhelyezése, ahol ezek az üzenetek orientálják, tájékoztatják és irányítják a vásárlók térbeli mozgását. Ilyen eszközökkel növelhető az egyes kereskedelmi központok kevésbé frekventált részeinek látogatottsága (emeletek, alagsor stb.). Az új, big data alapú IT-fejlesztések - mint a vásárlói mozgás elemzése (ki/belépés, bolton belüli, üzletek közötti mozgás iránya, gyakorisága) - szintén képet ad a vevők térhasználatáról, térképek, hőtérképek segítségével, amelyek szintén segítik a hatékonyabb lokális kommunikációt és értékesítést (http://www.prowiss.hu/).

Tágabb értelemben a marketingkommunikáció térbelisége nemcsak a földrajzi térre terjed ki, hanem általánosan minden külső és belső térre. A vállalatnak (illetve az ügynökségnek) meg kell határoznia, hogy a vállalati marketingkampányt melyik külső és belső terekben (kapcsolati hálózatokban, pl. Facebook, Instagram, LinkedIn) valósítja meg a legnagyobb hatékonyság érdekében, figyelembe véve a kampány céljait, a vállalat adottságait, a versenytársak kommunikációs tevékenységét és a célcsoport különböző preferenciáit.

\section{Tér és társadalmi felelősségvállalás}

A holisztikus marketingkoncepció fontos területe a társadalmi felelősségvállalás. Általánosan megfogalmazva: a „vállalati társadalmi felelősségvállalás az érintettek értékeinek és érdekeinek beépítése az üzleti működésbe" (Braun $2015,27$.$) . Sok területen a térbeliség a társadalmilag felelős marketingben is je-$ len van implicit módon.

Legnyilvánvalóbban a vállalat és a természeti környezet viszonyában jelenik meg ez a kapcsolat. A vállalatok felelősségvállalása a környezeti fenntarthatóság érdekében óhatatlanul felvet földrajzi térbeli szempontokat. A vállalatoknak székhelyük, telephelyeik, stratégiai céljaik, tevékenységük (és számos egyéb tényező szempontjából) kell kiválasztaniuk azokat a földrajzi helyeket, ahol aktívan részt vesznek a környezeti fenntarthatóság megvalósításában. Például a vállalat 
munkatársai fákat ültetnek a cég székhelye melletti parkban, a vállalat megújuló energiaforrások felhasználásával csökkenti a szén-dioxid-kibocsátást stb. Az, hogy a vállalat hogyan képes a stratégiai céljai és a környezeti fenntarthatóság között hosszú távon összhangot teremteni, jól példázza a Coca-Cola Magyarország Kft. környezeti felelősségvállalása a magyarországi dél-dunai szakaszon található Szabadság-szigeten (szabadsagsziget.hu). A cég - küldetésének és stratégiájának megfelelően - a szabadság eszméjéhez kapcsolódva választotta ki azt a földrajzi területet (Szabadság-sziget), melynek környezeti rehabilitálásában részt vesz. Vagyis a földrajzi hely és annak rehabilitálása egyrészt a vállalat környezeti felelősségvállalását tükrözi, másrészt integrálható a vállalati kommunikációba, annak szerves részét képezve.

Hasonló földrajzi vonatkozású kérdés a vállalatok társadalmi orientációja és felelőssége is. Ebben az esetben is ki lehet (kell) választani olyan társadalmi csoportokat, melyek támogatása hozzájárul a cég jó hírének növeléséhez. Olyan helyen müködő közösségek, csoportok kiválasztása kívánatos, melyek támogatása a vállalat hosszú távú (profit)céljaihoz (is) hozzájárul. E szervezeteknek, közösségeknek (legyenek akár a földrajzi térben vagy a kibertérben) kapcsolódniuk kell a vállalathoz, a földrajzi térbeli vagy kapcsolati „,közelségük” kiemelten fontos. A földrajzi közelségre jó példa a Győri Audi ETO KC, ahol a vállalat a helyi kézilabdacsapatot támogatja, vagy a helyi kisvállalkozó, aki a települési falunap megvalósításához járul hozzá. A kapcsolati közelség fontosságát példázzák egyes művészeti galériák, melyek kezdő művészek első nyilvános megjelenését biztosítják, vagy vállalatok, melyek fiatal tehetségeknek biztosítanak ösztöndíjakat bizonyos szakmákban.

A földrajzitér-orientáció megjelenik a vállalatok törvényes és etikai normákat szem előtt tartó viselkedésében is. Magyarországon (területi alapon) a vállalatok kétszintű jogi szabályozási környezetben működnek, az országos és helyi szabályozáson kívül figyelembe kell venniük az egységes európai uniós normákat is. Más országokban (ahol a területi autonómia is magasabb szintü) e mellett tartományi/megyei (középszintü) szabályozás is létezik, így a vállalatoknak a területi közigazgatás különböző szintjeihez tartozó rendelkezések betartásával kell müködniük.

A kötelező jogi szabályozás mellett figyelmet kell fordítani a nem kötelező szabályokra, etikai kérdésekre, melyeknek szintén azonosíthatók a térbeli vonatkozásai. A vállalatok rendszerint önként felvállalnak olyan nem kötelező normákat, ajánlásokat, gyakorlatokat, melyekből általában valamiféle (üzleti vagy egyéb) előnyük származik. E magatartásnak is lehet térbeli relevanciája olyan vállalatoknál, melyek szorosan kötődnek egy-egy természeti tájhoz (pl. a Tokaji borvidék borászatainál, a Balaton-parti települések turisztikai vállalkozásaiban stb.). Egy-egy sajátos etnikai régióban működő vállalkozás is figyelemmel lehet a többségi és kisebbségi nemzetiségi csoportokra, ahogy ezt az OTP Bank teszi például Szlovákiában a magyar nemzetiségűeknek nyújtott anyanyelvi szolgáltatásaival (www.otp.sk). 


\section{A kapcsolati marketing térvonatkozásai}

A holisztikus marketing másik meghatározó eleme a kapcsolati marketing, melynek célja hosszú távú, kölcsönös előnyökön nyugvó kapcsolat kialakítása és fenntartása az üzleti partnerekkel, szállítókkal, vevőkkel stb. Gazdasági, műszaki és társadalmi előnyök révén a vállalat csökkenteni tudja tranzakciós költségeit (Kotler 2001; Mandják, Szántó 2011).

A kapcsolati marketing számos társadalomtudományi diszciplínához kapcsolódik: a közgazdaságtudományhoz (tranzakciós költségek), a politikatudományhoz (hatalomelmélet), a szervezettudományhoz (erőforrások), a szociológiához (társadalmi hálózatok), a jogtudományhoz (szerződéselmélet). A kapcsolati marketingben több vonatkozásban megjelenik a térbeli dimenzió is. (Révész 2011)

A térbeliség úgy is felmerül, hogy a vállalat és partnerei közötti kapcsolat kialakításának és fenntartásának milyen jellegü és nagyságú költségei vannak (közgazdasági megközelítés). Minél közelebb van egymáshoz a vállalat és beszállítója a földrajzi térben, annál jobban képesek kiaknázni a földrajzi közelségből fakadó előnyöket (Benko 1992). Ezt igazolják a sikeres vállalati klaszterek (például a Szilícium-völgyben működő technopolisz, az Audi és beszállítóinak győri koncentrációja vagy a budapesti Falk Miksa utcában összpontosuló műkereskedelem). A földrajzi közelség fontos a vevők esetében is, ahol a „közelség” megnyilvánulhat gyorsabb és könnyebb információcserében, az árak jobb ismeretében stb.

A telekommunikációs és szállítási költségek csökkenése ellenére sem tapasztalható a korábban kialakult centrum-periféria viszonyok átrendeződése, sem globális, sem makro- vagy mezoregionális szinten. A személyes kapcsolat és az ebből fakadó „,bennfentes” információk jelentősége továbbra is kiemelt fontosságú (szociológiai megközelítés) (Gál 2012).

A földrajzi vagy kapcsolati közelségben működő kormányzati szervekkel, önkormányzatokkal folytatott vállalati kommunikáció is előnyös lehet (politikaelméleti megközelítés). Egy nemzeti dohánybolt nemcsak a kormányzati jogszabályi előírásoknak kell, hogy megfeleljen, de a zavartalan müködés érdekében együtt kell, hogy működjön a helyi önkormányzattal, valamint a településen müködő állami és önkormányzati ellenőrző és rendészeti szervekkel (közterület-felügyelet, Nemzeti Fogyasztóvédelmi Hatóság), továbbá a rendőrséggel. E példa kapcsán a szerző saját tapasztalata is azt mutatja, hogy bármelyik helyi vagy országos ellenőrző, illetve erőszakszervezet jelentősen meg tudja könnyíteni vagy nehezíteni a dohánytermékeket és italokat forgalmazó vállalkozás működését, hozzájárulhat sikerességéhez vagy éppen üzleti kudarcához. A kapcsolati marketing fontosnak bizonyul a kiskereskedelmi üzletek nyitva/zárva tartásának szabályozásában is, különösen azokban az országokban, ahol a nyitva tartást nem állami, hanem helyi vagy regionális szinten szabályozzák (Kovács, Sikos T. 2016). 
Összességében tehát megállapítható, hogy a kapcsolati marketing tervezése, szervezése során - a vállalat és partnerei közötti kapcsolatmenedzsment hatékonysága és eredményessége szempontjából - fontos a térbeli szempont.

\section{A belső marketing ,tere”}

A belső marketing tere a vállalat, célzottjai a vállalatnál dolgozó vezetők, alkalmazottak. Cél, hogy a vállalat jövőképével, küldetésével, stratégiájával a lehető legjobban azonosuljanak azok, akiknek feladata ezek megvalósítása. Így a belső marketingmunka szorosan kapcsolódik az adott vállalat szervezeti felépítéséhez és rendszeréhez. Ezáltal a belső marketing a vállalati szervezeti struktúrán keresztül, indirekt módon kapcsolódik a külső földrajzi terekhez. A földrajzi divíziók szerint felépített szervezeti rendszerek vagy a kiterjedt értékesítői, képviselői hálózattal működő vállalatok számára a belső marketing nemcsak a hatékony belső kapcsolattartás miatt fontos, hanem lehetőséget biztosít arra, hogy a különböző földrajzi térben (telephelyeken) dolgozók a lokális piacokról mélyreható és specifikus információkat szerezzenek és osszanak meg a vállalat többi szervezeti egységével (Kotler, Keller 2006). Ennek hatékonysága különösen fontos lehet például a gyógyszerforgalmazó, kereskedelmi vagy gyorséttermeket üzemeltető vállalati szervezetek esetében.

A vállalati térhasználat sajátosságainak feltárása szintén fontos a hatékony belső marketingmunka szempontjából. A vállalati épített környezet és annak munkavégzési, kommunikációs, pihenési stb. célú használata nemcsak szociológiai szempontból fontos (Berger 2013), hanem a vállalati marketingüzenetek gyors célba juttatására és elterjesztésére is szolgál.

A belső marketing hatékonyságát nemcsak a vállalat külső terei, az irodák mérete, elhelyezkedése, a közös használatú ebédlők, kávézók stb. elérhetősége, nagysága, használhatósága befolyásolja, hanem a vállalat alkalmazottai közötti kapcsolatok is. Az alkalmazottak és vezetők közötti formális és informális kapcsolatok hálózata, ezek topológiája és dinamikája és a hálózatok közötti erős és gyenge kapcsolatok - mint általában más társadalmi hálózatok esetében - nagyon fontosak (Granovettert idézi Barabási 2003).

\section{Geomarketing - szemlélet és eszközrendszer}

Az eddig leírtakban a térbeliség és a marketing kapcsolatának sajátosságait vizsgáltuk. Ezek után szükségesnek tartjuk a területi, térbeli szempontokat (is) szem előtt tartó és értelmező geomarketing fogalmi keretrendszerének tisztázását. Értelmezésünkben a geomarketing egyrészt szemléletmód, másrészt gyakorlat, 
amely áthatja a marketingtervezés és megvalósítás egészét. A geomarketing mint szemléletmód olyan általános térszemlélet a marketingben, mely a legtágabban értelmezi a teret a marketing minden részében. A geomarketing mint gyakorlat pedig magában foglalja mindazokat a fogalmi, modellezési, tervezési, elemzési ismereteket, eszközöket és eljárásokat, melyek segítségével a térbeliséget integráló marketingmunka hatékonyan valósítható meg.

A marketingben tehát - értelmezzük akár szemléletmódként, akár vállalati gyakorlatként - explicit (jól azonosítható, direkt) és implicit (kevéssé közvetlen, nem evidens) módon, széles körben azonosíthatók területi, térbeli problémák. A marketingszemléletet, illetve -gyakorlatot - annak függvényében, hogy a területi, térbeli jelleg mennyire markánsan jelenik meg - három egymásra épülö, hierarchikus csoportba soroltuk. Modellünkben megkülönböztetünk részleges, szűk és általános értelmezéseket (1. ábra).

A részleges értelmezés azon szemléletmód és vállalati gyakorlat, melynek keretében a kifejezetten könnyen azonosítható területi problémákra fókuszálnak. Ezek elsősorban olyan marketing-részterületek, ahol a (földrajzi) területiség nyilvánvalóan jelen van: telephelyválasztás, hálózatfejlesztés, logisztika stb. Az ilyen vállalatoknál a területi problémák legfontosabb elemeivel (a külső terekkel) foglalkoznak, számos területi/térbeli vonatkozás rejtve marad, illetve nem kezelik azokat tudatosan.

1. ábra: Területiség és térbeliség a marketingben Regionality and spatiality in marketing

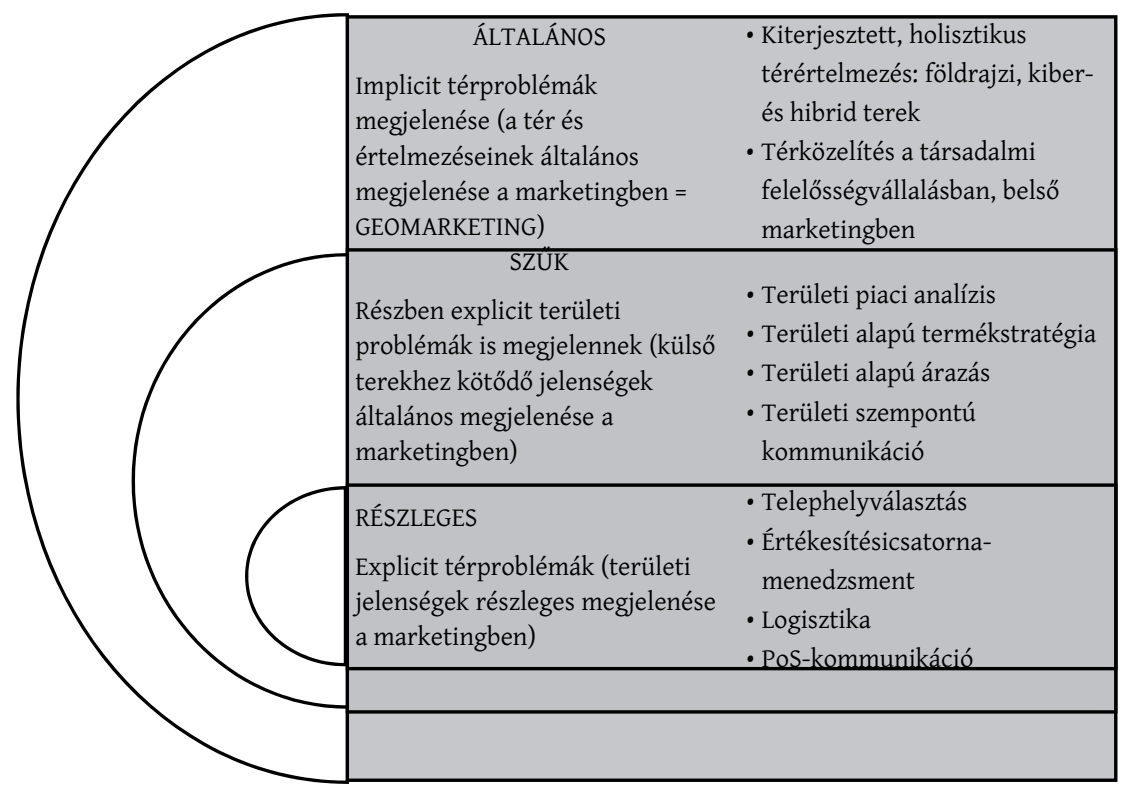

Forrás: saját szerkesztés. 
A szűk értelmezésben a területi, földrajzi problémák általánosan megjelennek a vállalati marketingben. A területiség itt már nemcsak „csatornapolitika”, hanem a vállalat számos területi vonatkozású problémát azonosít: a termékmenedzsment, az árazás, a kommunikáció stb. területi vonatkozásait is tudatosan kezelik. A területi probléma azonban itt is elsősorban külső, földrajzi terekhez kötődik. A tér általánosabb értelmezése nem jelenik meg, vagy nem tudatos.

Az általános értelmezés, azaz a geomarketing szerint a tér fogalmának értelmezése és vállalati folyamatokban történő azonosítása általános. A teret a vállalat nemcsak külső, földrajzi térként értelmezi, hanem belső, kapcsolati térként és szubjektív térként is. A vállalat e komplex térszemléletet integrálva alakítja célrendszerét, marketingstratégiáját és annak megvalósítási lépéseit.

Modellünkkel azt kívánjuk leírni, hogy a területi és térbeli szemlélet milyen szinteken vihető be a marketingszemléletbe és -gyakorlatba, és a vállalatok a térbeli nyitottságuk alapján milyen csoportokba sorolhatók. Míg a részleges megközelítés esetében csak néhány területen jelenik meg a földrajzi tér és annak hatása a vállalati működésre, addig a szűk megközelítésben a vállalkozás már az egész integrált marketingtevékenységét területi szempontok figyelembevételével alakítja. Az általános értelmezés során a vállalat a teljes (holisztikus) marketingrendszerét térbeli és területi szempontok szerint kezeli, tekintettel a különféle (külső és belső, földrajzi és kiber-, objektív és szubjektív) térbeli és térbeni viszonyokra.

\section{Összegzés}

Tanulmányunk a marketing és a tér kapcsolódási pontjait vizsgálta. A regionális tudományi és marketing-szakirodalmi forrásokra támaszkodó elméleti áttekintéssel az volt a célunk, hogy rámutassunk az alkalmazott üzlettudomány (marketing) térbeli vonatkozásaira. Bemutattuk a térelmélet idevágó értelmezéseit és a marketing fogalmi meghatározásait. Kotler holisztikus marketingkoncepciójára építve áttekintettük a marketing egyes részterületeinek térkapcsolódásait, végül meghatároztuk a geomarketing fogalmát és értelmezési lehetőségeit.

A marketinggondolkodásban és -eszközrendszerben eddig a térbeliség kevéssé jelent meg, szüken értelmezték a térbeliséget, alapvetően értékesítési csatornákra vonatkozó és telephelyválasztási problémák megoldására. Célunk az volt, hogy rámutassunk a térbeliség általános jelenlétére a marketingben, különös tekintettel a térvonatkozású terméktervezés, árképzés, kommunikáció stb. részterületeire. A gyakorlati alkalmazások és példák sorával illusztráltuk a vállalati marketingben fontos külső és belső terek sajátosságait, valamint kapcsolódásait a marketingmunkához.

Elméleti áttekintésünkkel azt szeretnénk elérni, hogy egyre több elméleti és gyakorlati „marketinges” ismerje fel a térmarketingben, vagyis a geomarketingben rejlő lehetőségeket. 


\section{Irodalom}

Barabási A. L. (2003): Behálózva. Magyar Könyvklub, Budapest

Bauer A., Berács J. (2006): Marketing. Aula Kiadó, Budapest

Benedek J. (2002): A földrajz térszemléletének hullámai. Tér és Társadalom, 2., 21-39.

Benko, G. (1992): Technológiai parkok és technopoliszok földrajza. MTA RKK, Budapest

Berger V. (2013): A tér problémája Anthony Giddens társadalomelméletében. Replika, 1., 25-54.

Berki M. (2015): A térbeliség trialektikája. Tér és Társadalom, 2., 3-18. http://doi.org/bmnd

Braun R. (2015): Vállalati társadalmi felelősségvállalás - A vállalatok politikája. Akadémiai Kiadó, Budapest

Cliquet, G. (ed.) (2006): Geomarketing. methods and strategies in spatial marketing. ISTE, Newport Beach

Douglas, B. (2008): Achieving business success with GIS. John Wiley \& Sons, New York http://doi.org/fcsdrr

Dusek T. (2013): Tér és közgazdaságtan. L’Harmattan, TIT Kossuth Klub, Párizs, Budapest

Enyedi Gy. (2002): A regionális tudomány. MTA RKK ATI jubileumi konferenciája, Kecskemét

Erdősi F. (2014): A térértelmezés néhány problémája, szempontjainak sokfélesége. Tér és Társadalom, 1., 5-27.

Faragó L. (2012): Térértelmezések. Tér és Társadalom, 1, 5-26.

Gál Z. (2012): A pénzügyi tér és a regionális tudomány frontvonalai - Lengyel Imre vitaindító tanulmányának apropóján. Tér és Társadalom, 1., 87-111.

Grimshaw, D. J. (2000): Bringing geographical information systems into business. John Wiley \& Sons, New York

Jakobi Á. (2007): Az információs társadalom térbelisége. ELTE, Budapest (Regionális Tudományi Tanulmányok; 13.)

Józsa L. (2014): Marketingstratégia - A tervezés gyakorlata és elmélete. Akadémiai Kiadó, Budapest

Kotler, P. (2001): Marketing Management. Prentice-Hall, Upper Saddle River

Kotler, P., Keller K. L. (2006): Marketingmenedzsment. Akadémiai Kiadó, Budapest

Kotler, P., Keller K. L. (2012): Marketingmenedzsment. Akadémiai Kiadó, Budapest

Kovács A. (2013): A Vértes Center és az Omega Park bevásárlóközpontok versenye - az optimális telephelyválasztás hatása az üzleti sikerre. In: Bernschütz M., Deés Sz., Kenéz A. (szerk.): eset@marketing.edu: marketing esettanulmányok: kihívások és megoldások a magyar piacon. Akadémiai Kiadó, Budapest, 221-237.

Kovács A., Sikos T. T. (2016): A vasárnapi zárvatartás hatása a fogyasztói magatartásra Magyarországon. Földrajzi Közlemények, 3., 229-244.

Kozák Á. (2010): A településtípus és a regionalitás összefüggései a fogyasztással és fogyasztói életstílussal. Tér és Társadalom, 4., 143-159.

Kozma G. (1995): Városmarketing mint a helyi gazdaságfejlesztés egyik lehetséges eszköze. Tér és Társadalom, 1-2., 37-54.

Krugman, P. (1999): Földrajz és kereskedelem. Nemzeti Tankönyvkiadó, Budapest

Lengyel I. (2010): A regionális tudomány „térnyerése”: Reális esélyek vagy csalfa délibábok. Tér és Társadalom, 3., 11-40.

Lengyel I., Rechnitzer J. (2004): Regionális gazdaságtan. Dialóg-Campus Kiadó, Budapest, Pécs

Longley, P. A., Clarke, G. (eds.) (1996): GIS for business and service planning. Wiley, Cambridge, New York

Mandják T., Szántó Z. (2011): Az üzleti kapcsolatok menedzselésének gondolati modellje. Vezetéstudomány, 1., 5-16.

Marshall, A. (1920): Principles of economics. Book V: General relations of demand, supply and value. Introductory: On markets. Macmillan, London

Mészáros R. (2001): A kibertér társadalomföldrajzi megközelítése Magyar Tudomány, 7., 769-779.

Nemes Nagy J. (2009): Terek, helyek, régiók. Akadémiai Kiadó, Budapest

Pick, J. (ed.) (2004): Geographic information systems in business. Idea Group Publishing, Hershey

Piskóti I. (2012): Régió- és településmarketing. Akadémiai Kiadó, Budapest

Rechnitzer J. (2005): Tükör által nem elhomályosítva (A posztmodern, a paradigmák, a main stream és a csábítás ördöge a regionális tudományban). Tér és Társadalom, 3-4., 1-12.

Rechnitzer J. (2016): A területi tóke a városfejlődésben - A Györ-kód. Dialóg Campus, Budapest, Pécs

Rekettye G., Tóth T., Malota E. (2015): Nemzetközi marketing. Akadémiai Kiadó, Budapest

Rekettye G., Törőcsik M., Hetesi E. (2015): Bevezetés a marketingbe. Akadémiai Kiadó, Budapest 
Révész B. (2011): A kapcsolati markering és az információs technológia. PhD értekezés. PTE Gazdálkodástani Doktori Iskola, Pécs

Sikos T. T. (2000): Marketingföldrajz. VÁTI, Budapest

Sikos T. T. (2012): Budapesti bevásárlóközpontok. Területi Statisztika, 6., 583-591.

Soja, E. (1989): Postmodern geographies. The reassertion of space in critical social theory. Verso, London, New York

http://hvg.hu/kkv/20160607_Az_Auchan_is_megnyitja_az_online_aruhazat_Tesco_Prima_GRoby (Letöltés: 2016. szeptember 9.)

http://szabadsagsziget.hu/index.php?m=partnerek/1/coca-cola_magyarorszag_kft. (Letöltés: 2016. szeptember 12.)

http://www.gfk-geomarketing.com/ (Letöltés: 2016. december 27.)

http://www.otp.sk (Letöltés: 2016. december 27.)

http://www.prowiss.hu/2016/09/23/keocko-vasarloi-elemzo-megoldas/ (Letöltés: 2016. december 27.)

http://www.webshopexperts.hu/szeminarium (Letöltés: 2016. szeptember 10.) 